\title{
Anal Ulcer
}

National Cancer Institute

\section{Source}

National Cancer Institute. Anal Ulcer. NCI Thesaurus. Code C79536.

A painful tear in the lining of the anal canal, often accompanied by bleeding on defecation.

It is usually the result of a traumatic bowel movement or anal sexual penetration. 